\title{
Edupreneurship management in shaping the nation's character
}

\author{
Nurjaya Nurjaya $^{\left.1^{*}\right)}$, Akhmad Sobarna ${ }^{2}$, Azhar Affandi ${ }^{3}$, Heri Erlangga $^{4}$, Sarwani Sarwani $^{5}$ \\ ${ }^{1}$ Universitas Suryakancana, Cianjur, Indonesia \\ ${ }^{2}$ STKIP Pasundan, Cimahi, Indonesia \\ ${ }^{34}$ Universitas Pasundan, Bandung, Indonesia \\ ${ }^{5}$ Universitas Pamulang, Tangerang Selatan, Indonesia
}

\section{Article Info \\ Article history:}

Received Sep 27th, 2020

Revised Oct 30th, 2020

Accepted Nov 29th, 2020

\section{Keyword:}

Edupreneurship

Nation's character

\begin{abstract}
The character cannot be directly obtained,it is instantaneous but requires time with the custom of academic habits to become a necessity and ultimately to get entrepreneurial skills, the purpose of identifying students' entrepreneurial skills in supporting the nation's character. Mix method with Convergence Model and t-test analysis shows that there are differences in indicators of student entrepreneurial skills with character education treatment and those that are not. There is the lowest indicator on creative thinking and responding to global problems by $60 \%$ enough categories. so it needs to be improved in further research with edupreneurship designs that are characterized in preparation, teaching materials, resources and learning media that are adapted to technological developments.
\end{abstract}

Corresponding Author:

Nurjaya Nurjaya,

Universitas Surya Kencana

Email:nurjaya@unsur.ac.id

\section{Introduction}

Indonesian people to seize opportunities and compete at the local, regional, and global levels. Policy competition has become an international agenda. Indonesia is one of a small number of developing countries that implement competition policies. The mindset to take the initiative to open a business or entrepreneurship for practice the knowledge gained during the school bench has not been developed, it is also a lack of support from parents. Informing the entrepreneurial character oftentimes individuals having difficulty in developing it. Therefore, many of the individuals who cannot survive to be an entrepreneur. In Indonesia, the number of entrepreneurs is very minimal and is far from enough to create a prosperous Indonesian nation. (Ahmad Khoiri, Syifa, \& Mubin, 2018; Miterianifa, Trisnayanti, Khoiri, \& Ayu, 2019; Reis, 1999).

One of the considerations of soft skills in the form of entrepreneurship (entrepreneurship) needs to be developed is the results of a country's research will prosper if it has entrepreneurs at least $2 \%$ of the population. Indonesia is estimated that only 400,000 people are registered as independent entrepreneurs or around $0.18 \%$. Sad again if you look at data from August 2006 to February 2007 educated unemployment rose by $9.88 \%$ This reality becomes an important factor for someone to have attitude skills or life skills. Life skills (life skills) according to (Chaturvedi, 2011) there are two parts, namely hard skills that are oriented towards academic achievement and soft skills that include skills relating to oneself and those that relate to others. (Chaturvedi, 2011) revealed that a person not only relies on high intelligence to achieve life success but attitudes needed are appropriate to his environment. Vocational teachers in Wonosobo Regency rarely identify soft skills on the grounds that academic ability in the form of hard skills is more important, so the learning style is still verbalised, which is that the material does not take into account the attitudes reflected in life skills. Entrepreneurial ability is included in the category of interpersonal skills, stating entrepreneurship 
as a commitment to creating something new, to make something different, with a view to improving individual welfare and providing added value to society. The ability of entrepreneurial spirit can be described by the writer in the following Table 1.

Table 1. Indicators of Entrepreneurial Skill (A Khoiri \& Haryanto, 2018)

\begin{tabular}{lll}
\hline No & Indicator & Descriptor \\
\hline $\mathbf{1}$ & Willingness to work hard & - Keep trying Unyielding \\
& & - Ability to work. \\
$\mathbf{2}$ & Confidence & - Confidence to be an entrepreneur. \\
& & - Optimistic developing products \\
$\mathbf{3}$ & Honest and responsible & - Positive reaction to criticism \\
& & - Compete in a healthy way \\
$\mathbf{4}$ & Endurance & - Ready to bear the risk. \\
$\mathbf{5}$ & Perseverance and tenacity & - Manage finances carefully \\
$\mathbf{6}$ & Creative and constructive & - Innovation of existing products \\
$\mathbf{7}$ & Future-oriented & - Understanding the market situation of competitive pricing \\
\hline
\end{tabular}

In learning based on local potential, educational institutions through their practitioners must be more concrete in preparing learning programs that can truly encourage the growth and development of entrepreneurial spirits ranging from elementary schools to tertiary institutions (B. Susilo, 2016) An entrepreneurial attitude is also influenced by perceptions of the condition of the business environment in the form of natural resources, work motivation, and the quality of coaching (A. Khoiri, 2016) This makes a reference that to grow the ability of entrepreneurs with the use of local potential will be more effective than other learning because it can utilize all kinds of potential areas as business opportunities.

\section{Method}

Mixed Methods Research is a design research based on philosophical assumptions as the inquiry method. Mived Methods Research is also referred to as a methodology which provides deep philosophical assumptions show directions or give directions data collection and analyzing data as well a mix of quantitative and qualitative approaches through several phases of the research process. Mixed Method Research aims to overcome weaknesses in the approach quantitative as well as qualitative approaches.

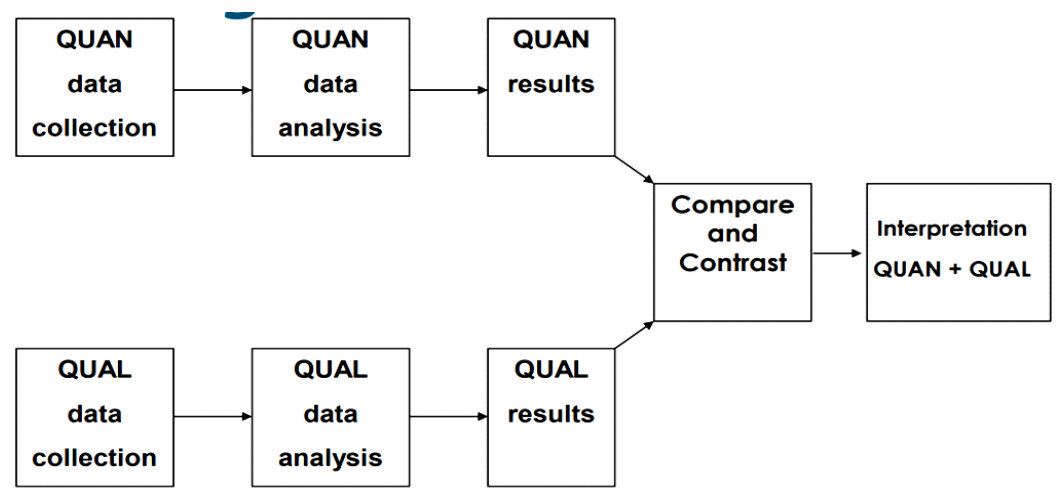

Figure 1. Convergence Model Mix Methods 


\section{Result and Discussion}

\section{Entrepreneur Skills}

The ability of entrepreneurial spirit with questionnaire questions in Figures 2 and 3.

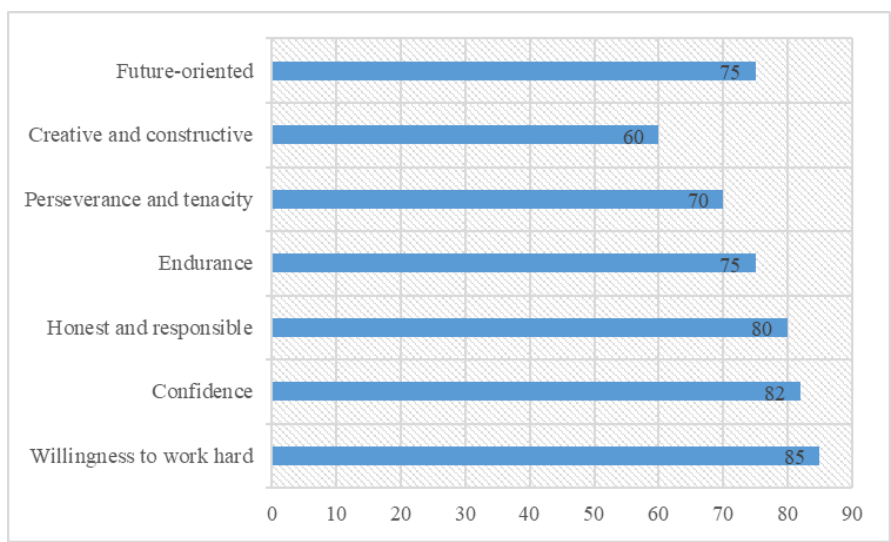

Figure 2. Entrepreneur Skills Indicator

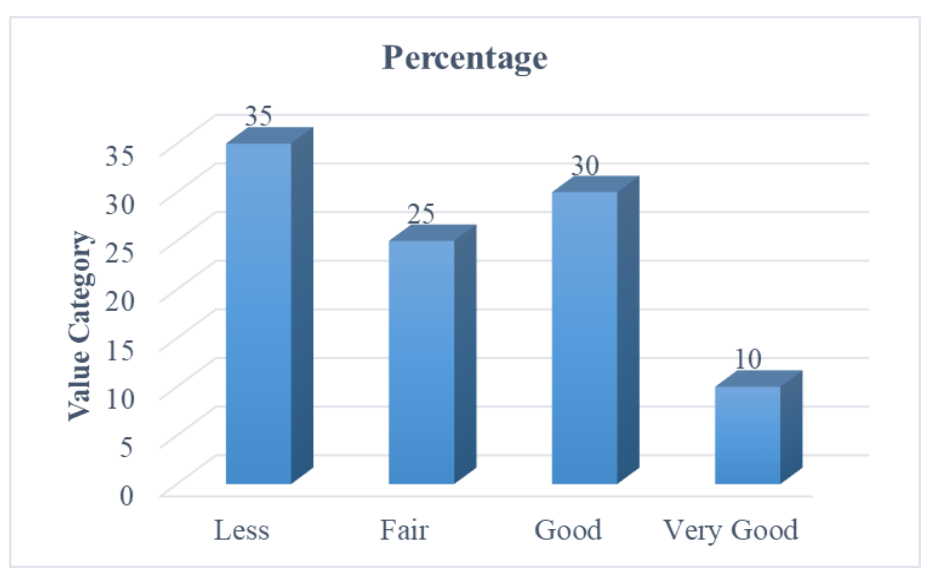

Figure 3. Entrepreneur Skills Indicator

The ability of students' entrepreneurial spirit is good there are $30 \%$ of students who are interested in entrepreneurial spirit, but need to be maximized in exploring ideas to train students in designing simple businesses on worksheets and survey sheets.

\section{Trial Results}

Table 2. Results of Entrepreneurial Soul Capabilities

\begin{tabular}{llcccc}
\hline No & Sampel & Average & Average & Percentage \\
\cline { 3 - 4 } & & Actual score & & Mutu Score & $(\%)$ \\
1 & A & 60 & 2,91 & 77 \\
2 & B & 55 & & 2,40 & 64 \\
\hline
\end{tabular}

After obtaining the average score based on Table 2, it is then analyzed using a different t-test to find out whether or not there is a difference in the ability of entrepreneurial spirit in Table 3. 
Table 3. T-Test on the Difference of Entrepreneurial Soul Skills

\begin{tabular}{cccccccc}
\hline $\mathbf{n}_{1}$ & $\mathbf{n}_{2}$ & $\mathbf{D k}=\mathbf{n}_{\mathbf{1}}+\mathbf{n}_{\mathbf{2}^{-}}$ & \multicolumn{2}{c}{ Uji t } & sig & Criteria & Conclusion \\
\cline { 3 - 7 } & & $\mathbf{2}$ & $\mathrm{t}_{\text {count }}$ & $\mathrm{t}_{\text {table }}$ & & & \\
34 & 34 & 66 & 3,45 & 1,99 & $5 \%$ & $\mathrm{H}_{1}$ Accepted, & Different \\
& & & & & & $\begin{array}{c}\text { tount } \\
>\mathrm{t}_{\text {table }}(3,45\end{array}$ & \\
\hline
\end{tabular}

Skills relating to others about how someone can make something, produce something that is of economic value for the welfare of individuals and society. Learning that is not only oriented to academic abilities but soft skills are also considered. There are $77 \%$ of the experimental class students who have entrepreneurial skills in either category and the control class of $64 \%$. This is a relatively large percentage difference because the activities of students in the experimental class are more oriented towards student learning activities through surveys to specialty food stores related to local potential and designing simple products. To train the independence of student learning through the principles of entrepreneurship that have been systematically designed. Students who use teaching materials based on local potential have more provision to have creative ideas about how to design something new, something useful, and have economic value for the welfare of themselves and the community (Sunarsi, 2019), Next is explained each indicator of student entrepreneurial skills.

\section{Willingness work to hard}

Willpower comes from intention, strong intention produces strong will. And this main capital that will make you be strong in facing all risks in entrepreneurship. Hard work Will without effort is equal to zero. Therefore all the hard will in the heart and conscience must be applied with hard work as well. Willpower + hard work will certainly make you a strong person. The hard face here means to not look at shame. Because in entrepreneurship you will feel shame that you have never felt before. Therefore, a strong person accompanied by a hard face will become an extraordinary person and deserve to be a successful entrepreneur. in the business world, obstacles, obstacles, challenges, and problems seem to be common. By having the mentality and character, and the strong will to succeed, an entrepreneur will be able to get through all of that smoothly. According to several successful entrepreneurs, this strong will is one of the things that must be possessed by an entrepreneur who wants to be successful (Maulida, Kusumah, \& Permana, 2016).

\section{Confidence}

Belief in one's abilities is very necessary for running a business. An entrepreneur who has the character to believe in the self ability will be better able to control doubts and anxiety in running a business. Because, with high self-confidence. Confidence or self-confidence interpreted as a belief in every individual has in his life, and how the individual views himself as such intact concerning self-concept (Lent \& Brown, 2019) can accept and appreciate others have the urge to achievers and can recognize strengths and its shortcomings. (Ayus Ahmad Yusuf, 2016) characteristic for assessing an individual's confidence, Believing in one's abilities or sure that is a belief in yourself against all phenomena that occur which related to individual abilities to evaluate and overcome the phenomenon that occurs, Act independent in making decisions,can act in making decisions to what is done independently without the involvement of others (Sunarsi, 2016).

\section{Honest And Responsible}

An entrepreneur is someone brave to try independently by mobilizing all resources and efforts to include the ability to produce something of higher value. An entrepreneur who has confidence and personality in starting his business will always apply the values of honesty in entrepreneurship. In terms of entrepreneurship, many of our competitors out there are working hard to be able to compete and get the maximum profit. So honesty is a very important attitude to be applied so that people and others can trust and believe in our business. Business based on honesty attitude will bring a good impact on the business itself (Bagautdinova et al., 2013; Victoria \& Elena, 2013).

For example, when our business product is experiencing product failure, we must be honest with consumers about the condition of our goods. That way consumers will judge us, to be honest in entrepreneurship. Because if we are not honest it will have a bad impact on our business. If we are not honest the customer will leave our product so that our profit will decrease. People whose businesses want to progress are people who are always optimistic and always apply the values of honesty in their business. 
Because one of the keys to the success of an entrepreneur in his business is the nature of honesty and trust of the consumer community towards him. Do not compromise on the importance of honesty in business. Once you get caught lying, not only one person knows, but many people. Now is the age of the internet and social media. All good and bad information quickly spread everywhere. Others will spread anything about yourself and your business. For that, let your good name be the talk of the community. Do not let the ugliness that spread and tarnished the good name that has been poorly formed.

In entrepreneurship, both producers and consumers must pay attention to ethics in entrepreneurship so that one another benefits. Ethics in entrepreneurship is related to the value of honesty that will bring entrepreneurs to success. The ethics is intended so that the prevailing norms are implemented so that each consumer feels valued, as well as the employer. With ethics, a friendly atmosphere between entrepreneurs can be established. So in entrepreneurship ethics there needs to be provisions that govern it. The value of honesty is in every aspect of life. Therefore, when someone considers himself as a social human, then he must learn to be an honest human being. In the student world many students open a business to develop their potential, but they still cannot know the ethics of entrepreneurship. Because in its business there are still many deviations that occur. Therefore in this attitude of entrepreneurship honesty is the main capital of the entrepreneur. This will foster an attitude of consumer confidence (customers) towards the services provided. The value of honesty covers various aspects of life related to one's behavior. Like the actions, words and deeds of the person. Because without honesty a business will not progress and is not trusted by consumers and business partners.

\section{Endurance}

Let and never give up resilient tough, strong, and not easily discouraged Never give up aspects of high commitment that is the attitude to survive to continue to want to achieve what is desired despite failures, obstacles, and obstacles., full of enthusiasm, not discouraged, strong hard work, and not giving up. An entrepreneur has high aspirations for success in managing his business activities, entrepreneurial aspirations are very high for success in managing business activities/business will be a driving force and endurance in dealing with all obstacles, obstacles, trials, and obstacles in entrepreneurship. Entrepreneurs must be ambitious want to progress (ambition drive) in carrying out business activities. (Ismail, Zain, \& Zulihar, 2015; Kolvereid \& Åmo, 2019).

Creativity to process and manage a business, from ideas and concepts, to being able to sustain itself, let alone to achieve a successful business. An entrepreneur is also required to develop innovative and attractive products for consumers, so that they can follow the trends and needs of consumers. In fact, it is possible for creativity and innovation to produce a product that is a trendsetter in the market. In addition, perseverance and a sense of responsibility are crucial to a person's success in managing his business. However, even before starting one's own business, an entrepreneur must at least have one thing that can determine the beginning of an entrepreneur's success, namely confidence. Often this thing escapes the attention of the entrepreneur. In fact, lack of confidence is a big problem in entrepreneurship, especially for young entrepreneurs, and those who are just starting their businesses.

\section{Perseverance and Tenacity}

Perseverance is formed by decision making and implies a stubborn, aimless goal and is random (except when stubborn desire to achieve an outcome is determined by self-affirmation motives). Unlike perseverance, which is always associated with students' desires and aspirations, stubbornly implies that you unconsciously follow a decision that you accidentally made or a decision made by someone else for students. Perseverance promotes progress, stubbornness, on the contrary, leads to a dead-end from behavior that is meaningless, unreasonable, and unproductive. Stubbornness can cause a person to lose awareness of reality, and as a result of paralysis inertia, perseverance helps maintain positive dynamics and maintain relationships with life. Learning is one of the scourges that is not easily conquered. There are various reasons why this can happen. Among other things because learning is boring so the subject or topic being studied does not interest them. Some think that learning in school has nothing to do with future dream work. These bad habits will certainly have a negative impact, especially if the individual is not able to motivate themselves to learn. The self is one's greatest enemy to move forward. Therefore, some tricks are needed to stay motivated to learn to get the opportunity to achieve a better future.

A new generation of professionals growing up must be more aware of the business environment than before the beliefs and responsiveness are needed to explore the role of individual sustainability competencies in developing entrepreneurial competencies. Student competence is very calculated to face the globalization 
of the economic era increasingly competitive competition will fail and decline if the nation's golden generation is not equipped with entrepreneurial skills (Lambrechts, Gelderman, Semeijn, \& Verhoeven, 2019; Portillo Navarro \& Millán Jiménez, 2016)

\section{Creative and Constructive}

The low this Indicator $60 \%$ score in figure 1 , so to instill and foster entrepreneurial mentality in students, there are several stages of achievement. First, the transformation of mindset to something positive, to attitudes and motives to change for the better. This is the main asset of a change in a better life. Second, the transformation of ways of thinking, from merely relying on logic to creative and innovative thoughts, sometimes even having to think in unusual ways. Third, Action; when the mindset has changed and the way of thinking has been fixed, the next step is to act which is to show the skills to look for opportunities in pouring creativity and innovation. Most entrepreneurial experts agree that entrepreneurial competencies in the form of the ability to think creatively and act innovatively become the main estuary of entrepreneurship education (Mulyani, 2014). then work networking creative is needed as a way to find success with many partners building relationships for mutual cooperation and greater business development (Mayer-Haug, Read, Brinckmann, Dew, \& Grichnik, 2013).

\section{Future Oriented}

Create a character is the process of making a person's habits or mindset Perfectly produced, interesting, and different can be distinguished from other people. The importance of character in entrepreneurship is character must become the foundation for intelligence and knowledge (brain and learning) of an entrepreneur. Relationship of significant social behavior on objects, groups, events, or a symbol. Three components of mutual support, namely: a cognitive component is a representation of what is agreed by the individual owner of the attitude, the affective component is a feeling that involves emotional aspects, and conative components is an aspect that is in accordance with the behavior that is owned by someone (Maulida et al., 2016). someone ready to endure the uncertainty to be involved in risky arbitration, arbitration is to buy goods and services at a certain price (fixed) in a market, so that it can be sold in another place or at another time, for a price which is uncertain in the future. There are so many opinions about the definition of entrepreneurship. Entrepreneurial mental attitude means personal or soul tendencies of a person or individual which results in action or behaviour, value and future (Thelken \& de Jong, 2020; Wiklund, Nikolaev, Shir, Foo, \& Bradley, 2019), either as an entrepreneur or as a potential become an entrepreneur.

With the times, the impression of entrepreneurship has changed to something more stylish and fashionable. Entrepreneurship today is no longer a suit, tie and rigid. But, more free and stylish. This is so that the scope of entrepreneurship becomes wider and can cover all groups. Since 2008, full-time job openings in the office have become increasingly scarce and few. Finally, the term Gig Economy emerged (this term is used to describe casual workers and part-time jobs). With advances in technology, Entrepreneurship is the right choice for anyone who wants to succeed in the "Fourth Industrial Revolution". Also in the future, entrepreneurs in any part of the world may not need to be limited anymore by national boundaries and to facilitate the business they founded, they can utilize their freelancers who are spread all over the world. entrepreneurship is not something as rigid as a few years ago. As entrepreneurs we must keep abreast of (global) times but still not lose ancient values such as ethics. Entrepreneurship must be supported by technology and sophisticated products, one must also be driven by persistent business intentions and a good understanding of the economy in order to become a good entrepreneur.

\section{Edupreneurship as a National Character}

The low competency and competitiveness of tertiary graduates make the absorption capacity of graduates in the field also low. As a result, many unemployed educated in various regions have difficulty finding work. "This is where the importance of instilling mental entrepreneurship for students who are internalized in education is often called edupreneurship", it wants to place entrepreneurship concepts and attitudes in the world of education. Education is often understood as a process of self-maturity integrated with entrepreneurs which in French means adventurers, risk-takers, and entrepreneurs. "Entrepreneurs are more than just entrepreneurs because there must be more value and something different. Entrepreneurs must be able to turn wreckage into gold through creativity and innovation in taking advantage of opportunities",

Students must have a character that is oriented to the task and results, the intention is the attitude of trust in carrying out the work so that the results will be satisfying. Processes and tasks that are carried out well and are full of trust, will provide good results and assessments as well. Another entrepreneurial character is risktaking and challenges and having a leadership spirit. Mental leadership and attitude are very important to be 
able to communicate well, be able to make plans, manage, and evaluate well, and like to advise and constructive criticism. This character will make students have a future-oriented attitude which means visionary and has a good perception and perspective for the future. mental and soul formation of student entrepreneurs to achieve success in the field of education. He added, "Edupreneurship is not intended to make students as entrepreneurs, but rather the formation of edupreneur character in the field of education. There are entrepreneurial values that need to be known and understood that can be internalized within learners in the learning process in class for success.

Learning is a facilitation process carried out by educators to students so that they can learn easily and at the same time each potential can be developed well. Along with this, class as one of the places of the process learning certainly needs to be well managed so that its existence becomes supporting factors the achievement of learning objectives, namely the achievement of competence and internalization of character values in students. Earlier it was stated that character education is basically an education score. Characters are often called value in action Character learning is basically about learning values and efforts help students to internalize the values (which underlie) character.

Good values internalized in students are what they are can make a good character. Good values cannot be limited in number, they are spread deep in various worlds of values (symbolic, empirical, aesthetic, ethical). The spread of values in the world These values are used as the foundation that character education needs to be included through various subjects and cannot be limited. Because of the difficulty of limiting the values of what needs to be taught that is necessary to focus on certain core values or prioritized values, where these values can be developed other values of goodness in nature wider. For the Indonesian nation, the core values are Pancasila values; Deity, Humanity, Unity, Society, and Social Justice. Entrepreneurial oriented learning can organize students in practicing bending, foresight, working hard and taking responsibility in facing the next life (Edi Purwanta dan Hulfah, 2018). Entrepreneurship education which is based on social reconstruction is relevant to solving social problems. Placement of social problem solving becomes the estuary of this theory (J.E. Austin, H. Stevenson, 2006) so that it has implications for the following points. First, that the content or material used is sourced from the potential around students the importance of relevant material needs of students so that it can attract students' interest and motivation to learn (Sukardi, 2001).

Based Figure 1 and 2 show Learning is the process of helping educators to help their students can learn happily and easily to achieve the learning goals that have been set. For students to learn in a fun and easy way, educators need to design learning well and planned, as well as placing and making efficient use of learning elements. The elements in question are (1) students, (2) educators, (3) learning objectives, (4) classroom management, (5) models, approaches, strategies, learning methods in developing learning model inagronomic education (Roman, 2015); (6) assessment of processes and results learn. Learning models with specific strategies can also improve entrepreneurial skills with aspects of students' processes and products (Rosana, ., \& A. Tiarani, 2012), Project-based learning is also effective in empowering entrepreneurial skills. Project based learning bargains (Mulyani, 2014). The benefits are very broad for students and teachers as well as a learning process to achieve competency attitudes, knowledge and skills With good and planned learning, the learning activities will focus and focus on every aspect to be achieved, including the process of integrating values entrepreneurship in classroom learning. Integrating the values of entrepreneurship in learning in the classroom is one way teachers can do for educational development entrepreneurship, where the goal is to prepare students to become academics an entrepreneur with character. Academic entrepreneurs here are students who have an entrepreneurial spirit with based on the values of character education. Furthermore, the entrepreneurial spirit of the character will be the capital for the realization of future ideals in every area of life by its competencies, whether business, economic, political, social, legal, health, even education.

Building character is the process of forming a person's habits or mindset in such a way that it is unique, attractive, and different or can be distinguished from others (Oviedo-Trespalacios, Angarita, Maestre-Meyer, \& Correa, 2015). The importance of character in entrepreneurship is that character must be the foundation for intelligence and knowledge (brains and learning) of an entrepreneur. Attitudes are relatively enduring organizations of beliefs, feelings, and behavioral tendencies towards socially significant objects, groups, events, or symbols. Three components of attitude are mutually supportive, namely: the cognitive component is a representation of what is believed by the individual owner of the attitude, the affective component is a feeling that involves emotional aspects, and the conative component is an aspect of the tendency to behave in accordance with the attitudes possessed by someone in competency learning (Maulida et al., 2016). 


\section{Conclusion}

Based on the t-test and descriptive analysis shows that there are differences in the scores of students' entrepreneurial results for each indicator. The lowest creative indicator is $60 \%$ of students cannot be explored directly before special treatment that reflects the student's entrepreneurial spirit, so that integrating values entrepreneurship into learning in the classroom is very important because it is in line with the importance of character education. the influence of differences in each indicator shows the gap in entrepreneurial skills possessed by students, so Its Integrating of entrepreneurship in the classroom means that two "benefits" can be achieved at once; experience entrepreneurship education and character education have been owned by students.

\section{References}

Ayus Ahmad Yusuf, A. H. (2016). Pengaruh Kepercayaan Diri Dan Semangat Kewirausahaan Terhadap Minat Menjadi Wirausaha. Al-Amwal, 8(2), 481-490.

B. Susilo, dan K. E. K. (2016). Baseline Research: Membangun Gerakan Desa Wirausaha. Yogyakarta: Yayasan Panabulu.

Bagautdinova, N. G., Goncharova, I. V., Shurkina, E. Y., Sarkin, A. V., Averyanov, B. A., \& Svirina, A. A. (2013). Entrepreneurial Development in a Corrupted Environment. Procedia Economics and Finance, 5(903), 73-82. https://doi.org/10.1016/s2212-5671(13)00012-9

Chaturvedi, A. (2011). Communicative Approach to Soft \& Hard Skills. India: Naraina College of Engineering \& Technology. VSRD-IJBMR, 1(1), 1-6.

Edi Purwanta dan Hulfah. (2018). Application Of E-Marketing In Entrepreneurship Learning For Student With Intellectual Disability. Cakrawala Pendidikan, 37(3), 391-399.

Ismail, V. Y., Zain, E., \& Zulihar. (2015). The Portrait of Entrepreneurial Competence on Student Entrepreneurs. Procedia - Social and Behavioral Sciences, 169(August 2014), 178-188. https://doi.org/10.1016/j.sbspro.2015.01.300

J.E. Austin, H. Stevenson, J. W. S. (2006). Social and Commercial Entrepreneurship: Same, Different, or Both? Entrepreneurship Theory and Practice.

Khoiri, A. (2016). Local Wisdom PAUD to Grow Student's Soft Skills (Study Cash: Development RKH On Science Learning). Indonesian Journal of Early Childhood Education Studies, 5(1), 14-17. https://doi.org/10.15294/ijeces.v5i1.11271

Khoiri, A., \& Haryanto, S. (2018). the 21St Century Science Skills Profile Based Local Wisdom Education (Tourist Attractions and Typical Foods in Regency of Wonosobo). Jurnal Penelitian Dan Pengabdian Kepada Masyarakat UNSIQ, 5(3), 361-371. https://doi.org/10.32699/ppkm.v5i3.485

Khoiri, A., Syifa, A., \& Mubin, N. (2018). Potential Local Physics Based Learning of Jepara District To Improve Science Process Skills and Students Entrepreneurship. Formatif: Jurnal Ilmiah Pendidikan MIPA, 8(1), 57-68. https://doi.org/10.30998/formatif.v8i1.2365

Kolvereid, L., \& Åmo, B. W. (2019). Incorporated entrepreneurship in Norway: Propensity and endurance. Journal of Business Venturing Insights, 11(December 2018). https://doi.org/10.1016/j.jbvi.2019.e00120

Lambrechts, W., Gelderman, C. J., Semeijn, J., \& Verhoeven, E. (2019). The role of individual sustainability competences in eco-design building projects. Journal of Cleaner Production, 208, 1631-1641. https://doi.org/10.1016/j.jclepro.2018.10.084

Lent, R. W., \& Brown, S. D. (2019). Social cognitive career theory at 25: Empirical status of the interest, choice, and performance models. Journal of Vocational Behavior, 115(June), 103316. https://doi.org/10.1016/j.jvb.2019.06.004

Maulida, A. N., Kusumah, I. H., \& Permana, T. (2016). Karakteristik Sikap Mental Wirausaha Mahasiswa Dalam Bidang Otomotif. Journal of Mechanical Engineering Education, 3(1), 9. https://doi.org/10.17509/jmee.v3i1.3187

Mayer-Haug, K., Read, S., Brinckmann, J., Dew, N., \& Grichnik, D. (2013). Entrepreneurial talent and venture performance: A meta-analytic investigation of SMEs. Research Policy, 42(6-7), 1251-1273. https://doi.org/10.1016/j.respol.2013.03.001

Miterianifa, Trisnayanti, Y., Khoiri, A., \& Ayu, H. D. (2019). Meta-analysis: The effect of problem-based learning on students' critical thinking skills. AIP Conference Proceedings, 2194(December). https://doi.org/10.1063/1.5139796

Mulyani, E. (2014). Developing an Enterpreneurship Education Project-Based. Cakrawala Pendidikan, XXXIII/no., 50-61.

Oviedo-Trespalacios, O., Angarita, L. P., Maestre-Meyer, M., \& Correa, C. B. (2015). Building the Life-long 
Learning Competence in Undergraduate Engineering Students with a Laboratory Practice in Learning Curve. Procedia - Social and Behavioral Sciences, 174, 2021-2026. https://doi.org/10.1016/j.sbspro.2015.01.870

Portillo Navarro, M. J., \& Millán Jiménez, A. (2016). Moderators elements of entrepreneurship. Gender differences. Suma de Negocios, 7(15), 47-53. https://doi.org/10.1016/j.sumneg.2016.02.002

Reis, T. (1999). Unleashing The New Resources and Entrepreneurship for The Common Good: A Scan, Synthesis And Scenario For Action. Battle Creek, MI: W.K. Kellogg Foundation.

Roman, I. (2015). Development of Agronomic Education by Student-centred Learning. Procedia - Social and Behavioral Sciences, 180(November 2014), 441-447. https://doi.org/10.1016/j.sbspro.2015.02.142

Rosana, D., . S., \& A. Tiarani, V. (2012). Five Strategies of Entrepreuneurship Learning Untuk Menghasilkan Real Entrepeuneur (Model Pendidikan Entrepreuneurship Di Perguruan Tinggi). Jurnal Cakrawala Pendidikan, (1), 82-96. https://doi.org/10.21831/cp.v0i1.1468

Sukardi. (2001). DESAIN Model Prakarya dan Kewirausahaan Berbasis Ekonomi Kreatif Berdimensi Industri Keunggulan Lokal Sukardi MODEl Design OF Prakarya and entrepreneurship With creative economy based and local QUality of Industry dimension. Cakrawala Pendidikan, XXXVI(2001), 114124.

Sunarsi, D. (2016). Pengaruh Minat, Motivasi Dan Kecerdasan Kognitif Terhadap Prestasi Belajar (Studi Kasus Pada Mahasiswa Program Studi S-1 Manajemen. Fakultas Ekonomi. Universitas Pamulang. Thn. Akademik 2015-2016). Proceedings (Vol. 1, No. 1).

Sunarsi, D. (2019). The Analysis of The Work Environmental and Organizational Cultural Impact on The Performance and Implication of The Work Satisfaction. Scientific Journal of Public Administration, 9 (2), 113-122.

Thelken, H. N., \& de Jong, G. (2020). The impact of values and future orientation on intention formation within sustainable entrepreneurship. Journal of Cleaner Production, 266, 122052. https://doi.org/10.1016/j.jclepro.2020.122052

Victoria, D., \& Elena, L. (2013). Moral and Ethical Conceptions of Entrepreneurs: Cross-cultural Aspects. Procedia - Social and Behavioral Sciences, 86, 318-322. https://doi.org/10.1016/j.sbspro.2013.08.571

Wiklund, J., Nikolaev, B., Shir, N., Foo, M. Der, \& Bradley, S. (2019). Entrepreneurship and well-being: Past, present, and future. Journal of Business Venturing, 34(4), 579-588. https://doi.org/10.1016/j.jbusvent.2019.01.002 